\title{
Impact of historical land-use changes on greenhouse gas exchange in the U.S. Great Plains, 1883-2003
}

\author{
Melannie D. Hartman, ${ }^{1,4}$ Emily R. Merchant, ${ }^{2}$ William J. Parton, ${ }^{1}$ Myron P. Gutmann, ${ }^{3}$ Susan M. Lutz, ${ }^{1}$ \\ and Stephen A. Williams ${ }^{1}$ \\ ${ }^{1}$ Natural Resource Ecology Laboratory, Colorado State University, Fort Collins, Colorado 80523-1499 USA \\ ${ }^{2}$ Institute for Social Research, University of Michigan, P.O. Box 1248, Ann Arbor, Michigan 48106-1248 USA \\ ${ }^{3}$ National Science Foundation, 4201 Wilson Boulevard, Suite 905, Arlington, Virginia 22230 USA
}

Abstract. European settlement of North America has involved monumental environmental change. From the late 19th century to the present, agricultural practices in the Great Plains of the United States have dramatically reduced soil organic carbon (C) levels and increased greenhouse gas $(\mathrm{GHG})$ fluxes in this region. This paper details the development of an innovative method to assess these processes. Detailed land-use data sets that specify complete agricultural histories for 21 representative Great Plains counties reflect historical changes in agricultural practices and drive the biogeochemical model, DAYCENT, to simulate 120 years of cropping and related ecosystem consequences. Model outputs include yields of all major crops, soil and system $\mathrm{C}$ levels, soil trace-gas fluxes $\left(\mathrm{N}_{2} \mathrm{O}\right.$ emissions and $\mathrm{CH}_{4}$ consumption), and soil nitrogen mineralization rates. Comparisons between simulated and observed yields allowed us to adjust and refine model inputs, and then to verify and validate the results. These verification and validation exercises produced measures of model fit that indicated the appropriateness of this approach for estimating historical changes in crop yield. Initial cultivation of native grass and continued farming produced a significant loss of soil C over decades, and declining soil fertility led to reduced crop yields. This process was accompanied by a large GHG release, which subsided as soil fertility decreased. Later, irrigation, nitrogen-fertilizer application, and reduced cultivation intensity restored soil fertility and increased crop yields, but led to increased $\mathrm{N}_{2} \mathrm{O}$ emissions that reversed the decline in net GHG release. By drawing on both historical evidence of land-use change and scientific models that estimate the environmental consequences of those changes, this paper offers an improved way to understand the short- and long-term ecosystem effects of 120 years of cropping in the Great Plains.

Key words: agricultural history; biogeochemical models; cropland; grassland; Great Plains (USA); greenhouse gas emissions, $\mathrm{GHG}$; land-use change; methane $\left(\mathrm{CH}_{4}\right)$ flux; nitrous oxide $\left(\mathrm{N}_{2} \mathrm{O}\right)$ emission from soil; pasture; soil carbon.

\section{INTRODUCTION}

European settlement of North America has involved monumental environmental change, brought on by the introduction of new agricultural practices to the region and the evolution of those practices over time. This paper offers an innovative way to understand the relationship between agricultural land use in the Great Plains of the United States and fluctuations in soil organic carbon (C) and greenhouse gas (GHG) emissions over the last 120 years, using methods that draw on both historical evidence of land-use change and scientific models that estimate the environmental consequences of those changes.

Recent research has produced significant improvements in the accuracy of regional GHG estimates, in

Manuscript received 7 January 2010; revised 20 July 2010; accepted 16 August 2010. Corresponding Editor: A. D. McGuire.

${ }^{4}$ E-mail: Melannie.hartman@colostate.edu part by refining the inputs to underlying environmental models (Parton et al. 2007). Here we describe an innovative approach to biogeochemical modeling using the DAYCENT model (Parton et al. 1998, Del Grosso et al. 2006), based on sub-regional representations of agricultural practices coupled with accurate historical county-level data about land use. This method builds on the successes of the CENTURY and DAYCENT models in simulating regional agricultural ecosystem dynamics (Gutmann et al. 2005, Parton et al. 2005, 2007, Del Grosso et al. 2006), and expands the land-use information available from earlier studies (Ramankutty and Foley 1999).

The Great Plains region is located in the middle of the United States, and includes 476 counties in Colorado, Iowa, Kansas, Minnesota, Montana, Nebraska, New Mexico, North Dakota, Oklahoma, South Dakota, Texas, and Wyoming that receive no more than 700 $\mathrm{mm}$ of annual rainfall on average, contain little land area above $1524 \mathrm{~m}$ (5000 feet) of elevation, and lie north 


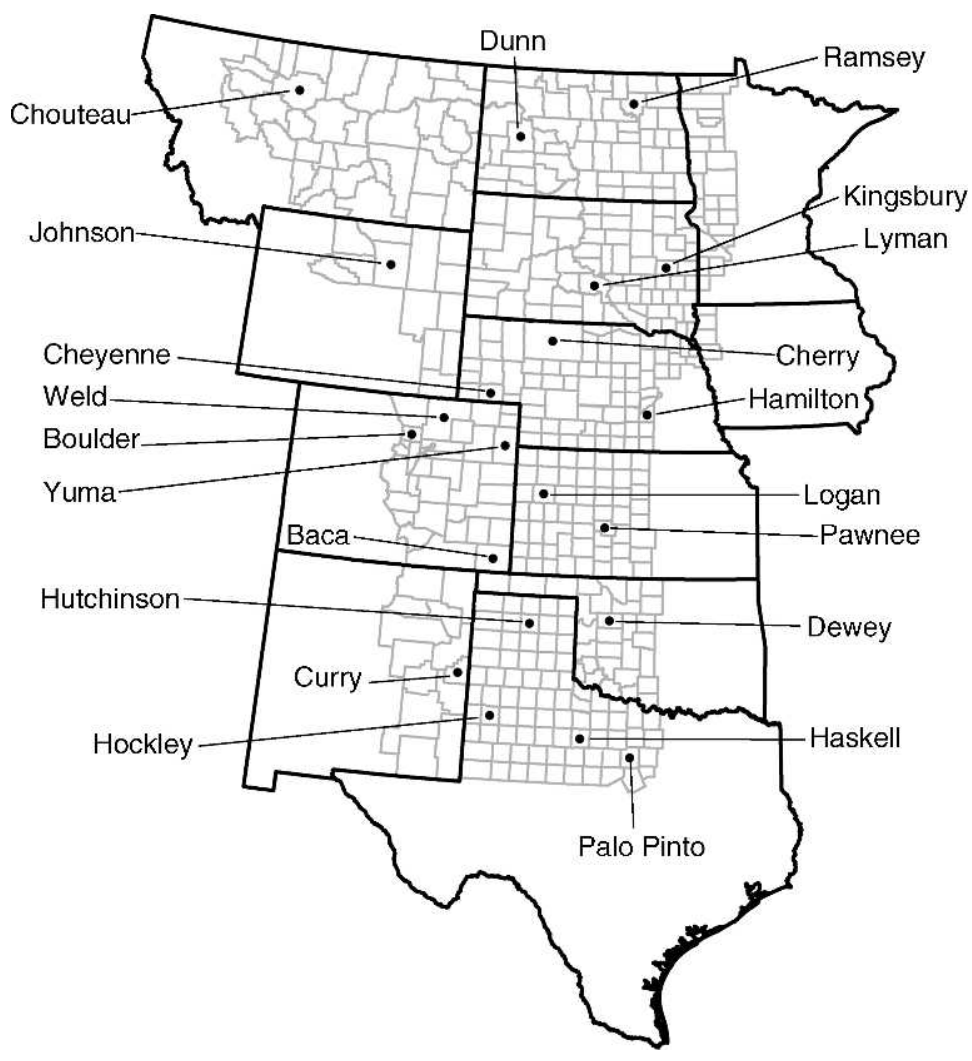

FIG. 1. The locations of the 21 representative counties in the Great Plains of the United States.

of the 32nd parallel. Environmentally, this region is homogeneous enough to form a coherent object of analysis, but also large enough to exhibit significant variation in climate and agricultural practice.

This article covers the period of nonnative settlement in the Great Plains, which began in the east in the 1860s and continued westward until the 1930s, though settlement was gradual and uneven. Settlers initially grazed cattle, but soon turned to cropping, with $60-70 \%$ of land eventually plowed in the eastern Great Plains and $<30 \%$ in the west (Cunfer 2005, Gutmann et al. 2005). The dominant crops have been winter wheat in the south and spring wheat in the north. Dryland corn was a major crop in the wetter eastern parts of the region, while cotton and sorghum were planted in the southern Plains.

Dryland agriculture predominated in the 19th and early 20th centuries (see Plate 1). Irrigation became widely practiced later, partly replacing dryland cropping beginning in the 1950s. The application of nitrogen $(\mathrm{N})$ fertilizer became common around 1950, and the amount increased over time. In recent years farmers have made use of reduced-till and no-till cultivation practices (Peterson et al. 1998), and a substantial amount of dryland cropland has been converted back to grassland since the 1950s in response to government soil-conservation programs (including the Conservation Reserve
Program since 1985) and low prices for agricultural products (Helms 1990).

Biogeochemical models in agricultural settings are driven by data reflecting the history or future projection of agricultural practices, coupled with the history of precipitation and temperature and the starting condition of the soil. While weather is known at a relatively fine scale, selecting the agricultural scale at which to set the model's other driver variables is a matter of importance. Even within a region as homogeneous as the Great Plains, agriculture varies widely. A major challenge in estimating biogeochemical models at a regional scale is finding the best balance between the simplicity of a single farming regime for the region and the complexity of actual on-the-ground practice. Earlier work (Parton et al. 2005) has shown that more detailed descriptions of agricultural practice, drawn from historical data, produce better results than do those that are less detailed.

In order to build an accurate model of cropping systems in the Great Plains counties without defining 476 county-specific land-use histories, we selected 21 counties spread across the region to represent the variety of climatic zones and agricultural practices (Fig. 1). This paper focuses on these 21 counties, but future work will extend our analysis to all 476 . Our primary source of historical land-use data is the U.S. Agricultural Census, supplemented by other sources of information about 
A) Year of maximum crop acreage

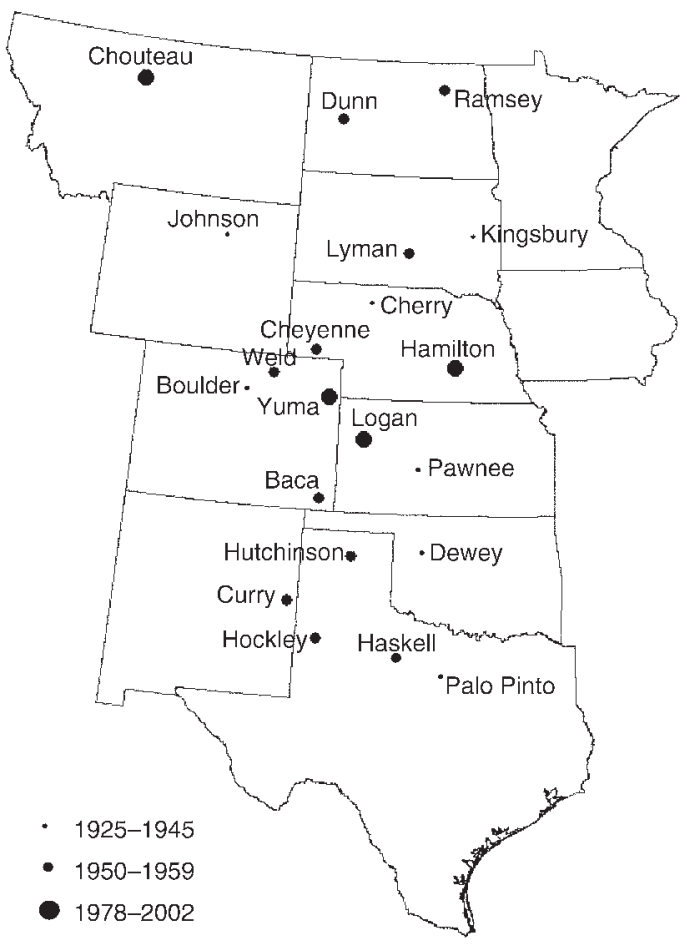

B) Percentage of ever-cropped land out of production in 2007

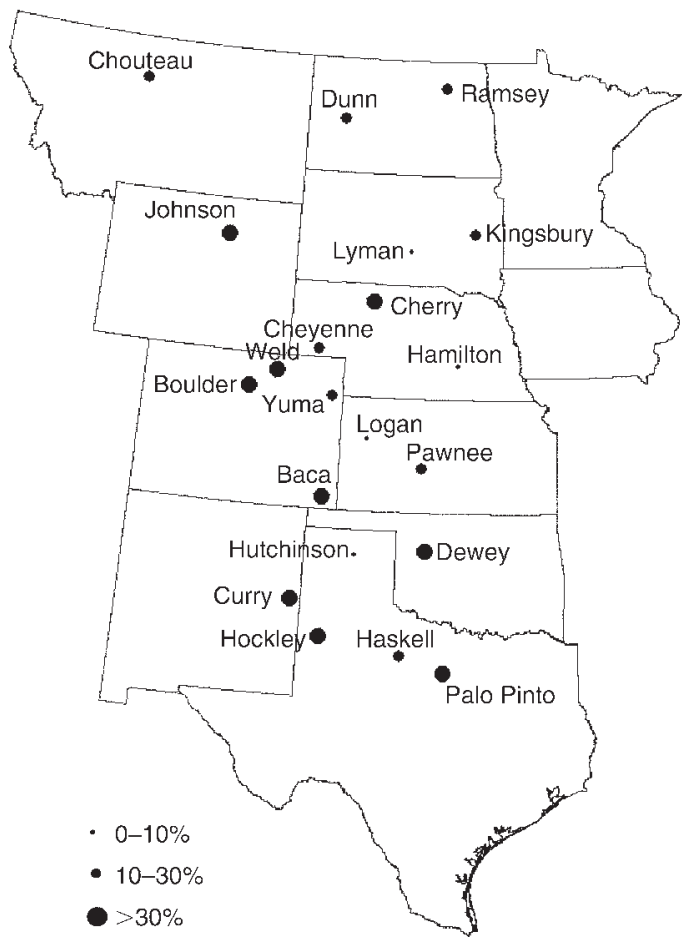

FIG. 2. The locations of the 21 representative counties showing (A) the year of maximum crop acreage, and (B) the percentage of ever-cropped land out of production in 2007.

historical changes in agricultural practice (Parton et al. 2005). The agricultural land-use history data, along with detailed data about weather and soil conditions, drive our simulations.

Beyond describing the methods we used to develop these biogeochemical simulations, this paper presents historical results about the transformation of major crop yields in the Great Plains from the late 19th century until the beginning of the 21st century, and provides an estimate of GHG fluxes and changes in soil organic C resulting from 120 years of cropping in this region. After reviewing Great Plains land-use history and describing the DAYCENT model, we detail the four steps of our modeling process: (1) parameterizing the DAYCENT model by summarizing detailed historical data and information from documentary sources into a set of 222 schedule files representing the full range of agricultural practices in each county; (2) calibrating and validating the DAYCENT model by comparing modeled yields to observed yields for both the 21 representative counties and 20 neighboring validation counties; (3) developing measures of model performance to test yield results; and (4) using the DAYCENT model to estimate soil $\mathrm{C}$, soil nitrous oxide $\left(\mathrm{N}_{2} \mathrm{O}\right)$ emissions, soil methane $\left(\mathrm{CH}_{4}\right)$ consumption, net $\mathrm{N}$ mineralization, and net GHG fluxes for select Great Plains counties and the region as a whole.

\section{Methods}

\section{Deriving Great Plains land-use history}

Using both historical data (Gutmann 2005a,b) and documentary sources, we have recovered the history of cropping in each of our 21 counties, following the method outlined in Parton et al. (2005). We then used the agricultural history of each county to write a set of schedule files detailing daily agricultural events for major land uses and crop types. The three major landuse practices in the region are dryland agriculture, irrigated agriculture, and the grazing of pasture land. Additionally, we found that farmers began to take portions of cropland out of production in the middle of the 20th century (Fig. 2), and later enrolled land in the Conservation Reserve Program (CRP), authorized by the 1985 Farm Bill (Food Security Act 1985); therefore, we created schedule files to represent grassland restoration.

For each of the 21 representative counties we developed one or more DAYCENT schedule files per major land use, although in some counties irrigation was not practiced, so irrigated schedules were not created for those counties. In contrast to our previous work (Parton et al. 2005), we did not limit ourselves to representing a county through a single dominant cropping structure and rotation for any period of time. In the following analyses we allowed for more than one simultaneous 
dryland and irrigated cropping structure and rotation in each county.

The resulting schedule files describe a small number of crops and rotations that account for all of the acreage in a county. As farm practices have changed over time, each dryland or irrigated schedule file evolves accordingly. In general, for any county, the 2000-year land-use history represented in each schedule file begins with approximately 1900 years of a native grassland specific to the county, for example a mix of $50 \%$ warm-season grasses and $50 \%$ cold-season grasses in Colorado and Nebraska. Beginning in the late 19th or early 20th century, the schedule files describe county-specific cropping or grazing practices that continue through simulation year 2003. We created more than one version of some schedule files (replicate schedule files) by staggering the starting and ending years of the crop rotations within the schedule file. For example, a cornwheat-fallow rotation might be represented by three separate schedule files so that our model can account for the fact that farmers planted each crop in each year. This modification allows us to calculate specific crop yields for a greater number of years and weather conditions. For each county, 7-16 schedule files represent pasture, dryland and irrigated crops with staggered rotation dates, dryland cropland converted to pasture, and CRP, (dryland cropland converted to grassland without grazing), for a total of 222 schedule files (Appendix A). Schedule files include sequences of time blocks, with each block specifying a unique set of agricultural practices in effect for the given years. Crop varieties represented by the schedule files change over time, with those used before 1940 having substantially lower yield potential and higher straw to grain ratios than current crop varieties.

\section{DAYCENT model description}

For this exercise we use the DAYCENT model, the daily-time-step version of the CENTURY model. CENTURY, which operates at a monthly time step, and DAYCENT, which operates at a daily time step, are both generalized ecosystem models that simulate the dynamics of $\mathrm{C}, \mathrm{N}$, and phosphorus (P) in grassland, forest, savanna, and agricultural systems (Metherell et al. 1993, Parton et al. 1993, 1998). DAYCENT includes a weekly time-step submodel for plant production and daily time-step submodels for trace-gas fluxes, nutrient cycling, water flow, and soil organic-matter (SOM) turnover (Parton et al. 1996, 2001, Del Grosso et al. 2000, 2006). DAYCENT calculates potential plant production and nutrient uptake as a function of soil water stress, leaf-area index, soil temperature, and incoming solar radiation, and limits actual plant production according to soil nutrient availability. The SOM submodel estimates nutrient mineralization, which depends on the decomposition of dead plant material and the turnover of SOM pools. This submodel therefore computes the cycling of above- and below- ground dead plant material and three types of SOM pools (active, slow, and passive). Soil organic matter C and $\mathrm{N}$, and $\mathrm{N}$-mineralization rates, represent values for 0-20 cm soil depth. Abiotic drivers for the DAYCENT model include observed daily precipitation and daily maximum and minimum temperatures; soil input variables include texture, bulk density, thickness, field capacity, wilting point, $\mathrm{pH}$, and saturated hydraulic conductivity for multiple soil layers.

The CENTURY and DAYCENT models have been thoroughly tested using data on observed plant production, soil organic matter, nutrient cycling, and trace gas $\left(\mathrm{N}_{2} \mathrm{O}\right.$ and $\left.\mathrm{CH}_{4}\right)$ fluxes from agricultural, grassland, and forest systems (Parton et al. 1993, 2005, Parton and Rasmussen 1994, Kelly et al. 1997, Del Grosso et al. 2008a). These tests indicate that CENTURY and DAYCENT can correctly simulate the impact of different cultivation practices, cropping systems, and organic and inorganic fertilizer use on observed changes in soil $\mathrm{C}$ and $\mathrm{N}$ levels, soil $\mathrm{N}$-mineralization rates, tracegas fluxes, and crop yields.

\section{Calibrating and running the DAYCENT model}

The DAYCENT model uses the historical schedule files, along with records of weather and observed soil properties, to predict crop yields and to estimate various measures of soil and system chemistry. Comparing predicted to observed yields allowed us to calibrate the model and further refine its estimates. For simulation years 1895-1979, we drive the model with VEMAP daily historical climate data (Kittel et al. 2004), and for simulation years 1980-2003 we drive the model with Daymet climate data (Thornton et al. 1997). The spinup period, year zero to approximately year 1894, is simulated by repeating daily VEMAP/Daymet 18952003 climate data over the entire period. Both VEMAP (resolution $0.5^{\circ}$ latitude $\times 0.5^{\circ}$ longitude) and Daymet (resolution $1 \mathrm{~km}^{2}$ ) daily climate data are available for the continental United States, and we extracted the meteorological records for the latitude and longitude of the centroid of each county. We acquired county-specific soil properties data-including percentage sand, percentage silt, percentage clay, bulk density, $\mathrm{pH}$, and soil depth-from the State Soil Geographic (STATSGO) Database (Soil Survey Staff, Natural Resources Conservation Service, United States Department of Agriculture, U.S. General Soil Map (STATSGO, available online). ${ }^{5}$ The soil characteristics for a given county represent the modal soil within the area of the county that has been identified as an agricultural region by the STATSGO data set.

Reported crop yield data came from the U.S. Census of Agriculture and the National Agricultural Statistics Service (NASS). The U.S. Census of Agriculture has compiled data since 1840, first at decadal intervals and

\footnotetext{
${ }^{5}\langle$ http://soildatamart.nrcs.usda.gov $\rangle$
} 
then every five years (available online). ${ }^{6}$ NASS has compiled annual agricultural data since the late 19th century, relying on surveys conducted in all counties of 44 states (Lokupitiya et al. 2007, USDA 2007). All NASS data were retrieved via the online database (QuickStats, available online), ${ }^{7}$ from which we could select yield data for specific crop types, growing practices, years, states, and counties. We converted the units of the reported yields from the Census of Agriculture and NASS databases (bushels, bales, or hundredweight per hectare) to $\mathrm{g} \mathrm{C} \cdot \mathrm{m}^{-2} \cdot \mathrm{yr}^{-1}$ in order to render them comparable to the model data, using cropspecific multipliers to convert reported yields to grams of dry matter and assuming $1 \mathrm{~g} \mathrm{C}$ per $2.2 \mathrm{~g}$ dry matter.

We calibrated the DAYCENT model by simulating annual county-level crop yields for each major crop (hay, corn, wheat, sorghum, cotton, soybeans, and sugar beets), graphing the time series of simulated yields against observed yields for each county by crop type, and then adjusting model parameters and inputs to increase or decrease simulated yields. Discrepancies between modeled and observed yields at this stage provided us with more information about historical changes in crop varieties, fertilization levels, and cultivation practices for each county, indicating how we needed to adjust the model's plant-growth parameters and inputs to improve the accuracy of our schedule files at each point in time. For example, if actual yields were greater than simulated yields for a given crop, we added more fertilizer or increased irrigation (within historically realistic limits), or chose a variety that had a higher grain-to-stalk ratio.

These calibration strategies allowed us to better simulate the complexities of farm practice. Farmers transitioned to higher-yielding crop varieties over time (such as hybrid corn [Griliches 1960], introduced in 1936, and the short and semidwarf wheat varieties introduced in the 1960s [Dalrymple 1988]), so crop varieties in our schedule files shifted accordingly. We reduced the intensity and frequency of plowing over time to mitigate the loss of soil organic matter and nutrients. Historically, residue removal was a common practice in early years, but not in later years, so we reduced residue removal over time, thereby increasing $\mathrm{N}$ inputs to the soil. Before 1950 we added manure to areas where this practice was known to occur, such as Weld and Boulder counties in northern Colorado (Clark 1904). After 1950, when farmers began to use synthetic fertilizer, we prescribed fertilizer inputs to the model, in amounts based on observed county-level fertilizer sales data (Ruddy et al. 2006). The resulting schedule files start with low fertilization rates in the 1950s, and these generally increase over time (Parton et al. 2007).

\footnotetext{
${ }^{6}\langle$ http://www.agcensus.usda.gov/ $\rangle$

7 http://www.nass.usda.gov/Data_and_Statistics/ QuickStats/1.0_index.asp $\rangle$
}

\section{Model verification and validation}

Following model calibration, we verified the simulated crop yield results for the 21 representative counties and validated the DAYCENT model output for 20 of the 21 counties. In these validation runs, we applied each county's schedule files to the adjacent county to the north (with the exception of Cherry, Nebraska, because the county to its north lacks data on observed wheat and corn yields), using soil parameters and weather drivers specific to the validation county, but without changing any other model parameters. For all counties we compared observed and simulated yields and computed several measures to evaluate model performance for irrigated and dryland wheat and corn in the validation counties and for all major crops in the verification counties: from linear regression, the $R^{2}$ correlation coefficient, slope, and intercept obtained by regressing observed yields on predicted yields; the mean absolute error (MAE); the root mean square error (RMSE); and the Modeling Efficiency (ME) (Janssen and Heuberger 1995) (Appendix B).

Comparison of the observed and simulated annual crop yields for dryland and irrigated wheat, corn, sorghum, and hay for the 21 representative counties (Fig. 3) shows that $R^{2}$ values tend to be higher for the irrigated crop yields (ranging from 0.59 to 0.76 ) than for the dryland crop yields (ranging from 0.28 to 0.73 ), with dryland and irrigated corn having the best fit to the observed-yield data and dryland hay and wheat having the lowest correlation $(0.28$ and 0.40$)$ to the observedyield data. The low correlation between model results and observed data for dryland hay is associated with uncertainty about management practices (e.g., mowing and fertilizer application). The lower $R^{2}$ value for dryland wheat yields reflects the inability of the model to simulate some of the year-to-year changes in yield associated with changes in the weather, and the fact that disease and hail damage are not simulated in the model. Table 1 presents a summary of the model-performance indices for crop yields in the 21 representative counties and the 20 validation counties. A comparison of the observed and measured model-performance yield statistics for all 41 counties reveals reduced model performance for dryland and irrigated corn and for irrigated wheat in the validation counties. However, model performance is higher in the validation counties for dryland wheat (Table 1). Appendix B shows a detailed comparison of the model-performance statistics for crop yield at the county level for representative counties and validation counties. Model performance varied among individual counties and among crops. For corn and wheat crops the $R^{2}$ correlations between simulated and measured yields were higher $60 \%$ of the time for the 21 representative counties compared to their corresponding validation counties (Appendix B).

Interannual changes in system $\mathrm{C}$ storage, along with annual soil $\mathrm{N}_{2} \mathrm{O}$ emissions and annual soil $\mathrm{CH}_{4}$ flux drive the net GHG budget for agricultural systems, 

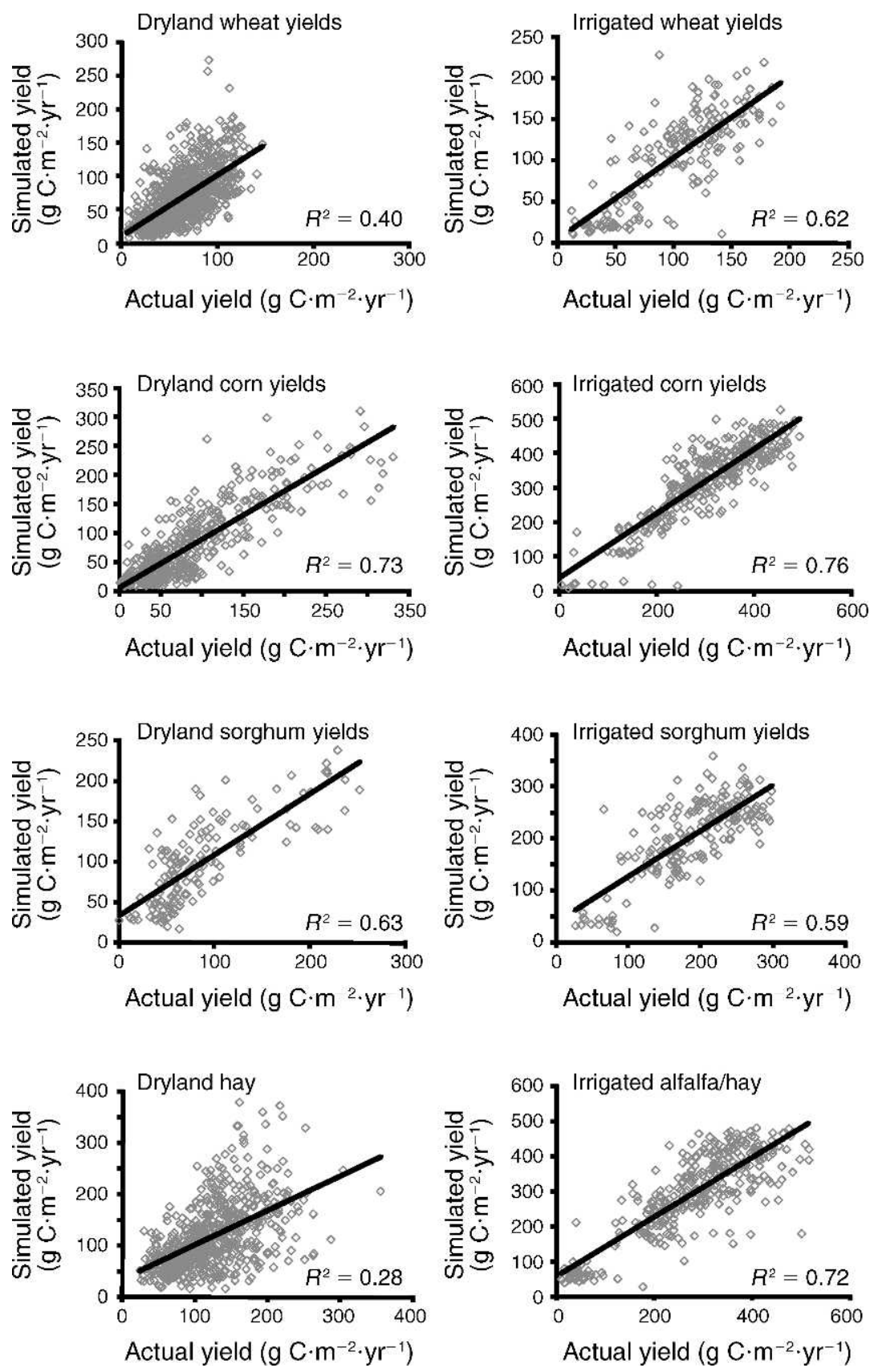

FIG. 3. Mean simulated yields vs. mean actual yields for four dryland and four irrigated crops for the 21 representative counties. Each open symbol represents the mean for a specific county in a specific year. The $R^{2}$ values shown here are different than the $R^{2}$ values shown in Table 1 because they were calculated from multiple predicted/observed pairs per year instead of from a single mean predicted/observed pair per year as in Table 1 .

ignoring anthropogenic emissions from fossil-fuel burning to run farm equipment or to produce synthetic fertilizers, and direct and indirect $\mathrm{N}_{2} \mathrm{O}$ and $\mathrm{CH}_{4}$ emissions from livestock. The DAYCENT model outputs include system $\mathrm{C}$ amounts as $\mathrm{g} \mathrm{C} / \mathrm{m}, \mathrm{N}_{2} \mathrm{O}$ flux as $\mathrm{g} \mathrm{N}_{2} \mathrm{O}-\mathrm{N} \cdot \mathrm{m}^{-2} \cdot \mathrm{yr}^{-1}$, and $\mathrm{CH}_{4}$ consumption as $\mathrm{g} \mathrm{CH}_{4}$ $\mathrm{C} \cdot \mathrm{m}^{-2} \cdot \mathrm{yr}^{-1}$. We convert the units of these three variables to $\mathrm{CO}_{2}-\mathrm{C}$ equivalents so they can be added together to compute the net GHG budget. We assume that a change in system $\mathrm{C}$ is due to the sequestration of $\mathrm{CO}_{2}$ by plants or the release of $\mathrm{CO}_{2}$ from heterotrophic respiration. To convert all components to $\mathrm{CO}_{2}-\mathrm{C}$ equivalents, we also assume that a kilogram of $\mathrm{N}_{2} \mathrm{O}$ has 298 times the 100year horizon global-warming potential of a kilogram of $\mathrm{CO}_{2}$, and that a kilogram of $\mathrm{CH}_{4}$ has 25 times the 100year horizon global-warming potential of a kilogram of 
TABLE 1. Model performance measures comparing simulated crop yields against observed yields for the major crop types in the 21 representative counties and the 20 validation counties in the U.S. Great Plains.

\begin{tabular}{|c|c|c|c|c|c|c|}
\hline \multirow[b]{2}{*}{ Counties } & \multicolumn{3}{|c|}{ Results of linear regression } & \multirow{2}{*}{$\begin{array}{l}\text { Mean absolute } \\
\text { error, MAE }\end{array}$} & \multirow{2}{*}{$\begin{array}{l}\text { Root mean square } \\
\text { error, RMSE }\end{array}$} & \multirow{2}{*}{$\begin{array}{c}\text { Model } \\
\text { efficiency, ME }\end{array}$} \\
\hline & $R^{2}$ & Slope & Intercept & & & \\
\hline \multicolumn{7}{|l|}{ Representative sample counties } \\
\hline Dryland corn† & 0.86 & 0.95 & -6.40 & 17.16 & 22.14 & 0.81 \\
\hline Dryland cheat† & 0.70 & 1.05 & 0.77 & 11.10 & 15.29 & 0.48 \\
\hline Dryland sorghum & 0.76 & 1.07 & 3.74 & 15.88 & 21.10 & 0.56 \\
\hline Dryland cotton & 0.94 & 1.01 & 10.63 & 22.61 & 29.69 & 0.92 \\
\hline Dryland hay & 0.50 & 0.88 & 10.49 & 25.34 & 31.93 & 0.19 \\
\hline Dryland oats & 0.90 & 0.99 & 11.73 & 25.42 & 33.05 & 0.88 \\
\hline Irrigated corn $\dagger$ & 0.94 & 1.10 & -18.38 & 26.22 & 37.44 & 0.92 \\
\hline Irrigated wheat $\dagger$ & 0.67 & 1.05 & -8.88 & 22.57 & 29.27 & 0.45 \\
\hline Irrigated sorghum & 0.79 & 1.10 & -16.95 & 30.35 & 42.64 & 0.67 \\
\hline Irrigated cotton & 0.90 & 0.99 & 10.92 & 24.40 & 32.87 & 0.89 \\
\hline Irrigated alfalfa & 0.93 & 0.92 & 33.60 & 31.01 & 38.06 & 0.91 \\
\hline Irrigated potatoes & 0.82 & 0.86 & 22.68 & 31.43 & 44.80 & 0.81 \\
\hline Irrigated soybeans and dry beans & 0.79 & 0.87 & 20.06 & 29.14 & 44.00 & 0.79 \\
\hline Irrigated sugar beets and potatoes & 0.81 & 0.92 & 17.38 & 37.97 & 58.27 & 0.79 \\
\hline Irrigated barley & 0.74 & 1.06 & -7.70 & 29.01 & 41.19 & 0.59 \\
\hline Irrigated sugar beets & 0.84 & 0.90 & 35.83 & 39.52 & 54.33 & 0.83 \\
\hline Irrigated dry beans & 0.88 & 0.89 & 25.72 & 27.06 & 39.06 & 0.87 \\
\hline Irrigated soybeans & 0.90 & 0.96 & 18.32 & 24.86 & 32.14 & 0.87 \\
\hline \multicolumn{7}{|l|}{ Validation counties } \\
\hline Dryland corn $\dagger$ & 0.74 & 0.89 & 6.60 & 20.01 & 28.68 & 0.70 \\
\hline Dryland wheat $\dagger$ & 0.77 & 1.15 & -7.70 & 12.04 & 15.41 & 0.58 \\
\hline Irrigated corn $\dagger$ & 0.90 & 1.11 & 3.37 & 39.71 & 52.33 & 0.82 \\
\hline Irrigated wheat $\uparrow$ & 0.54 & 1.02 & -1.31 & 26.51 & 36.83 & 0.12 \\
\hline
\end{tabular}

Note: The $R^{2}$ values shown here are different than the $R^{2}$ values shown in Fig. 3 because they were calculated from an annual mean predicted/observed pair instead of from multiple predicted/observed pairs per year as in Fig. 3 .

$\dagger$ Denotes crops included in the validation.

$\mathrm{CO}_{2}$ (Forster et al. 2007). The net GHG flux for any given year is equal to the change in total system $\mathrm{C}$ from the previous year, plus $\mathrm{N}_{2} \mathrm{O}$ flux and minus $\mathrm{CH}_{4}$ consumption. A positive value for the net GHG budget indicates a source of GHG to the atmosphere, and a negative value indicates absorption of GHG by the system, measured as $\mathrm{C}$ sequestration and $\mathrm{CH}_{4}$ consumption.

After validating and running the DAYCENT model for each schedule file in our 21 representative counties, and computing the 1860-2003 time series of annual net GHG flux associated with each, we extrapolate from these net GHG emissions results to estimate cumulative GHG fluxes over the entire Great Plains region. We first determine how much land to assign to each schedule file, distributing all land in each of the 21 counties among the schedule files for that county. The area assigned to each schedule file is based on the maximum amount of land ever cropped, the amount removed from cropping prior to and under CRP, and the proportion of remaining county land in each crop, determined by averaging crop areas from the 1978-2007 Agricultural Censuses. For each year, the annual per square meter net GHG flux from each schedule file is multiplied by the amount of land assigned to that schedule, and these results are aggregated by land-use category (dryland, irrigated land, restored grassland (land in CRP or otherwise out of production), and pasture). In aggregating, schedule files are included in the pasture category until cropping begins, then in the dryland or irrigated category depending on management practice, and are moved into the restored grassland category if and when cropping ends. These aggregate values are then divided by the total area in each land-use category in the 21 representative counties in each year to calculate an annual area-weighted flux for each land-use category. Finally, these annual per square meter weighted fluxes are multiplied by the amount of land in each category in each year in the whole Great Plains, and cumulated over years (Table 2).

\section{RESUlts}

The historical schedule files we developed for the 21 representative counties allow us to simulate and discuss the environmental impact of observed historical changes in Great Plains cropping systems, including the adoption of practices that increased yields dramatically. Our focus includes: (1) yields of all major crops, (2) soil C levels, (3) soil trace-gas fluxes $\left(\mathrm{N}_{2} \mathrm{O}\right.$ emissions and $\mathrm{CH}_{4}$ consumption), (4) soil $\mathrm{N}$-mineralization rates, and (5) the net GHG budget.

\section{Crop yields}

We computed five-year moving averages of simulated and observed yields for each crop by averaging simulated and observed yearly mean yields for the 21 representative counties for dryland and irrigated crops (Fig. 4). Model results and observed data for dryland 
TABLE 2. Cumulative greenhouse-gas (GHG) emissions for the entire Great Plains region for three time periods.

\begin{tabular}{lcccccc}
\hline \hline & \multicolumn{5}{c}{ Cumulative GHG emissions (g CO -C equivalents) } \\
\cline { 2 - 6 } Time period & Dryland cropland & Irrigated cropland & All cropland & Restored grasslands & Pasture & Total \\
\hline $1860-1949$ & $1.53 \times 10^{15}$ & $1.51 \times 10^{13}$ & $1.55 \times 10^{15}$ & 0.00 & $-7.95 \times 10^{12}$ & $1.54 \times 10^{15}$ \\
$1950-2003$ & $3.38 \times 10^{14}$ & $-2.44 \times 10^{13}$ & $3.13 \times 10^{14}$ & $-1.02 \times 10^{14}$ & $-2.34 \times 10^{13}$ & $1.88 \times 10^{14}$ \\
$1860-2003$ & $1.87 \times 10^{15}$ & $-9.37 \times 10^{12}$ & $1.86 \times 10^{15}$ & $-1.02 \times 10^{14}$ & $-3.13 \times 10^{13}$ & $1.73 \times 10^{15}$ \\
\hline
\end{tabular}

Notes: A positive value represents a net GHG flux to the atmosphere; a negative value represents a net GHG sink. Restored grasslands are dryland cropland returned to pasture or enrolled in CRP; pasture is land that was never cropped.

crops indicate that yields were generally low prior to 1950 and increased linearly from 1950 to 2004 for wheat, corn, hay, and cotton. Sorghum production peaked in 1990 and remained at peak levels through 2004. Yields have increased by more than $80 \%$ in dryland wheat and $300 \%$ in dryland corn since 1950 , while dryland cotton and hay yields have increased by only $50 \%$. Model results closely correspond to observed yield data, the

Five-year moving average, observed

Five-year moving average, model
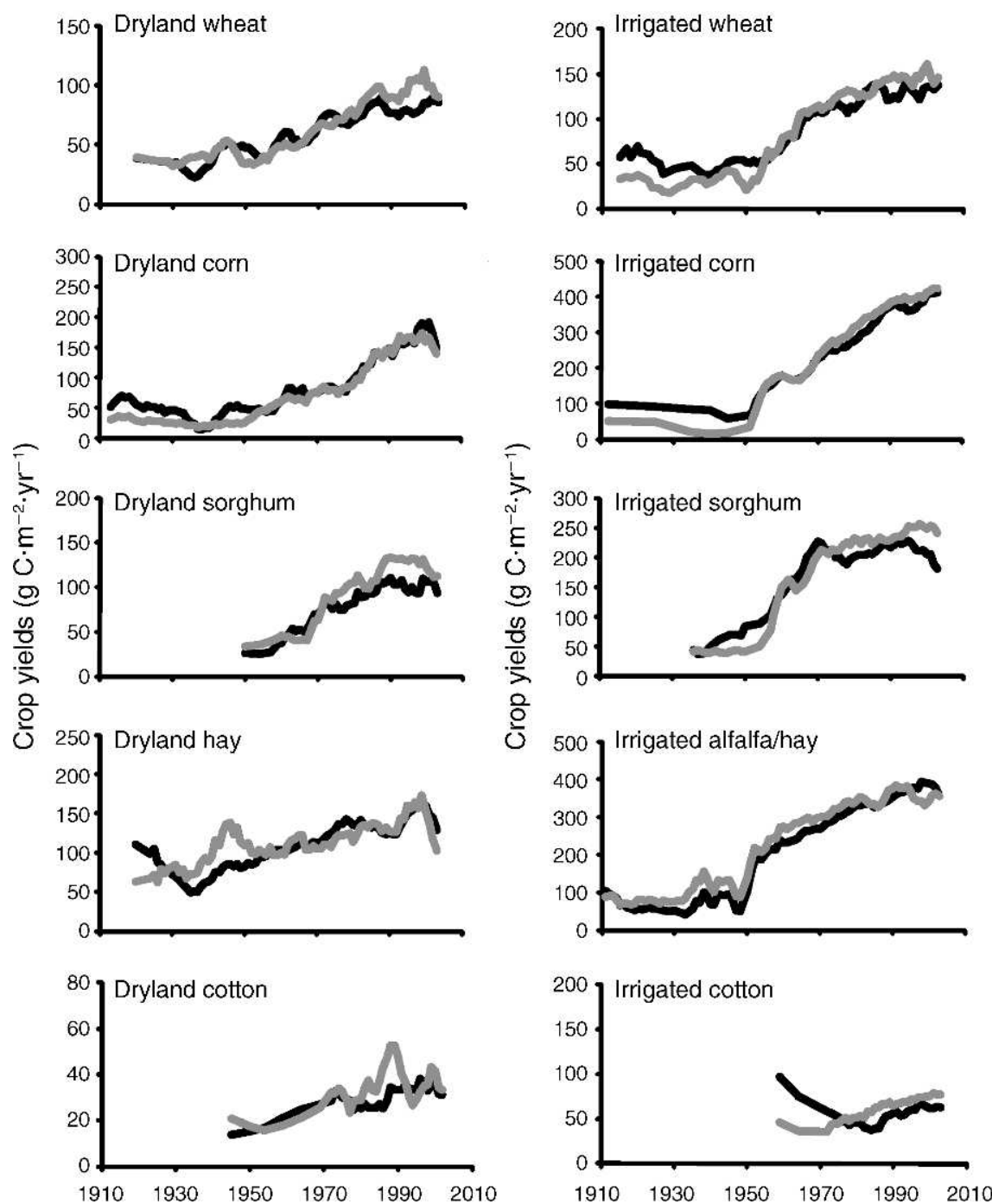

FIG. 4. The five-year moving average of simulated crop yields and of observed yields for five dryland crop types and five irrigated crop types for years 1910-2003 for the 21 representative Great Plains counties. The moving averages were computed from the mean of all 21 county crop yields in a given year (a single predicted/observed pair per year), and include only years when both simulated yields and observed yields were available. 
only major discrepancy being that the model tends to overestimate dryland wheat and sorghum yields during the 1990s. Yield trends for irrigated crops are similar to those for dryland crops, with dramatic increases in yields starting in 1950 for wheat, corn, sorghum, and alfalfa hay. Peak sorghum yields occurred in the 1970s, while wheat, corn, and alfalfa hay yields have increased continuously since the 1950s. Irrigated-cotton yields have increased slightly since the 1980s. The results presented in Figs. 3 and 4 show that the DAYCENT model can correctly simulate historical changes in mean crop yields for all major irrigated and non-irrigated crops grown in the Great Plains. However, year to year variations in crop yields are, in general, more accurately simulated for irrigated crops than for dryland crops (for example, Fig. 3 shows that the $R^{2}$ for dryland hay of 0.28 is much less than the $R^{2}$ of 0.72 for irrigated alfala/ hay).

\section{County-level impacts of land management}

In order to demonstrate the consequences of the different land management systems (pasture, dryland cropping, irrigated crops, CRP (USDA Conservation Reserve Program), and cropland abandonment) on ecosystem dynamics, we present the simulated impact of these practices on soil $\mathrm{C}$ dynamics, net $\mathrm{N}$ mineralization, soil $\mathrm{N}_{2} \mathrm{O}$ emissions, and aboveground production for three counties: Hamilton County, Nebraska; Yuma County, Colorado; and Weld County, Colorado (Figs. 5, 6, and 7), which represent a range of annual precipitation levels and irrigation practices.

The results for Hamilton County (Fig. 5) show that the initiation of dryland cropping in 1890 resulted in a rapid decline in soil $\mathrm{C}$, accompanied by increases in soil $\mathrm{N}$ mineralization and soil $\mathrm{N}_{2} \mathrm{O}$ fluxes, a result of increased decomposition of soil organic matter. From 1905 to $1950 \mathrm{~N}$ was removed from the soil system in grain and stover but not replaced with fertilizer (no fertilizer inputs until 1950), causing a general pattern of decreased soil $\mathrm{N}$ mineralization and $\mathrm{N}_{2} \mathrm{O}$ fluxes. Aboveground plant production increased immediately after the initial cultivation of the land, but the 19051950 decline in soil $\mathrm{N}$-mineralization rates caused a concomitant decline in yields. The initiation of irrigated corn cropping in 1950 reduced the impact of drought stress on plant growth. At the same time, $\mathrm{N}$ fertilizer was introduced to both dryland and irrigated cropping systems (increasing from $4-7 \mathrm{~g} \mathrm{~N} \cdot \mathrm{m}^{-2} \cdot \mathrm{yr}^{-1}$ in 1950 to $12 \mathrm{~g} \mathrm{~N} \cdot \mathrm{m}^{-2} \cdot \mathrm{yr}^{-1}$ currently). Together, irrigation and fertilization produced large increases in soil $\mathrm{C}, \mathrm{N}$ mineralization, soil $\mathrm{N}_{2} \mathrm{O}$ fluxes, and plant production. The increase in $\mathrm{N}$-fertilizer applications in dryland cropping after 1950 was accompanied by improved tillage practices and crop varieties. Model results for dryland cropping reveal the same pattern of increased soil $\mathrm{C}, \mathrm{N}$ mineralization, $\mathrm{N}_{2} \mathrm{O}$ emissions, and plant production from 1950 to the 1980s; however, because dryland cropping involved more water stress on plants,
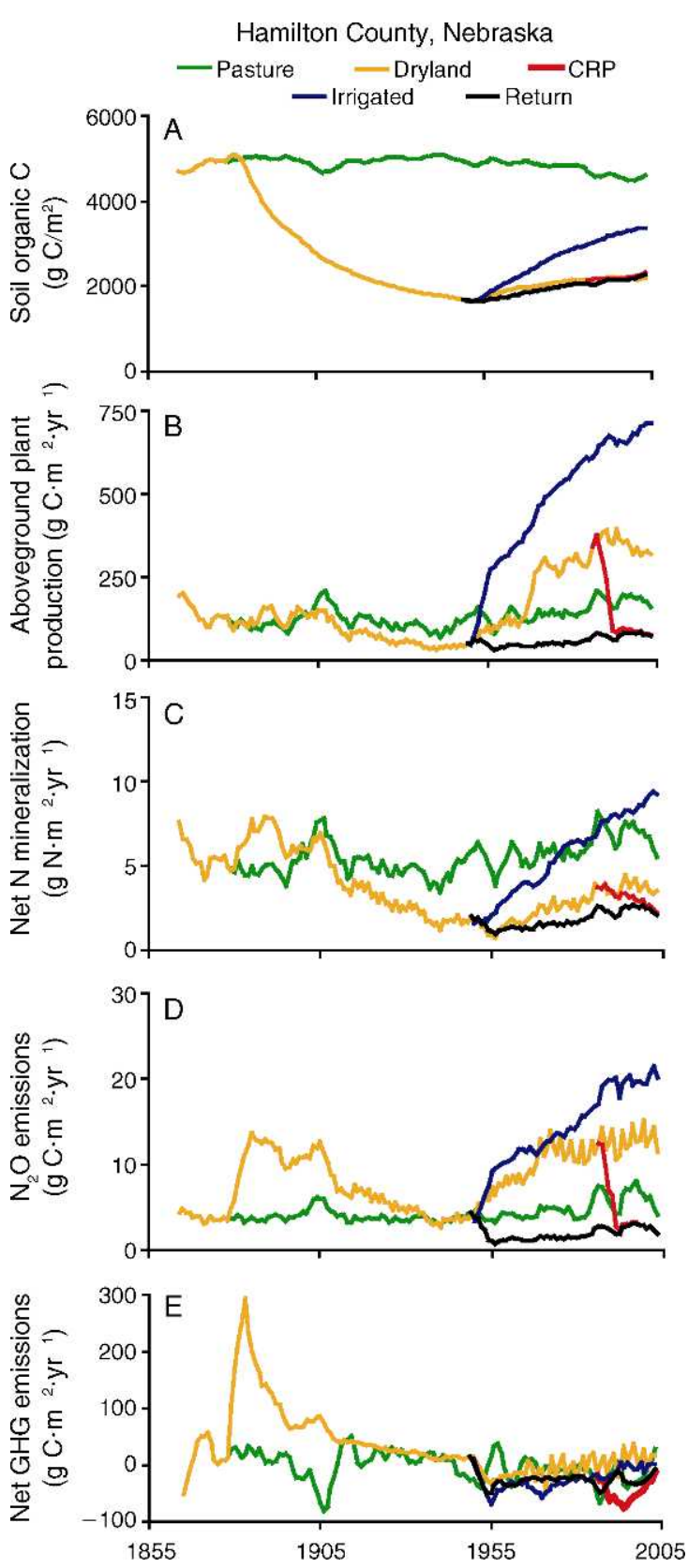

FIG. 5. Results for Hamilton County, Nebraska, USA, for: (A) soil organic carbon; (B) aboveground plant production; (C) net nitrogen mineralization; (D) $\mathrm{N}_{2} \mathrm{O}$ emissions; and (E) net greenhouse-gas (GHG) emissions, expressed as $\mathrm{CO}_{2}$ carbon equivalents for years 1860-2003, and five land-use classifications: grazed pasture (pasture), dryland agriculture (dryland), irrigated agriculture (irrigated), Conservation Reserve Program (CRP), and dryland cropland that was returned to grazed pasture (return).

the increases are substantially less than those observed for the irrigated crops.

Simulated net GHG fluxes in Hamilton County show a large release of GHGs to the atmosphere following the 1890 plowout (Fig. 5), a result of large reductions in soil $\mathrm{C}$ and enhanced soil $\mathrm{N}_{2} \mathrm{O}$ emissions. Net GHG 


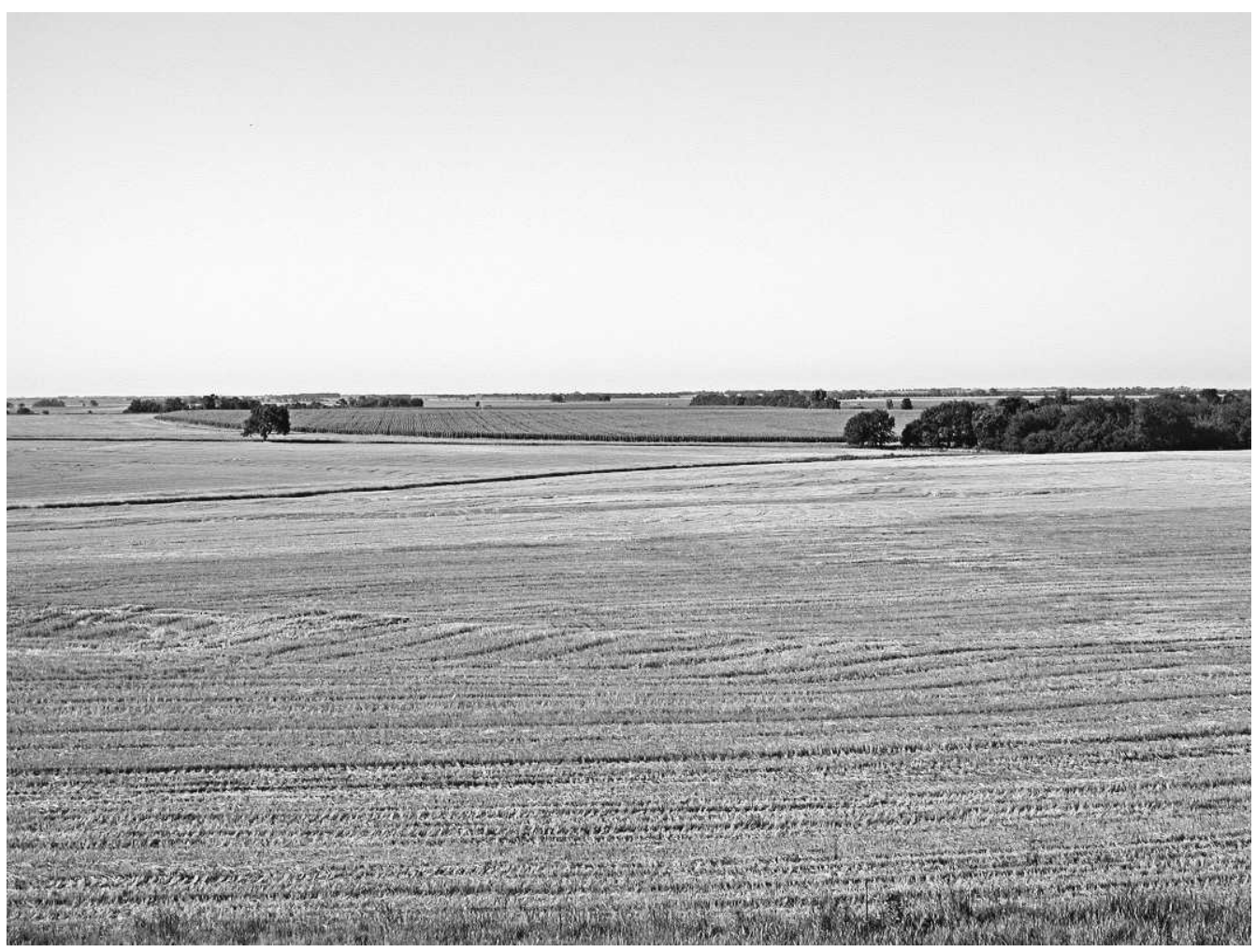

Plate 1. Harvested farmland in north-central Kansas (USA), July 2004. Photo credit: M. P. Gutmann.

emissions decreased gradually from 1900 to 1950 as the pace of soil $\mathrm{C}$ depletion slowed and as $\mathrm{N}_{2} \mathrm{O}$ emissions declined. The initiation of irrigation in 1950 resulted in a net sink (negative numbers) in GHG fluxes for 10 years as soil $\mathrm{C}$ was restored, but the increase in soil $\mathrm{N}_{2} \mathrm{O}$ fluxes (from the introduction of $\mathrm{N}$ fertilizer) after the 1970s again produced a net release of GHGs by year 2005. The results for the dryland cropping system show the same pattern, but with smaller net negative GHG fluxes from the 1950s to the 1990s. Soil C did increase in dryland cropping, but without irrigation it was a much more gradual process and was more easily offset by the increased soil $\mathrm{N}_{2} \mathrm{O}$ emissions resulting from the use of $\mathrm{N}$ fertilizer.

Restoring pasture on previously cropped dryland fields beginning in 1950 (Fig. 5, return) produced slow increases in soil $\mathrm{C}$ and plant production, and a decrease in $\mathrm{N}$ mineralization and soil $\mathrm{N}_{2} \mathrm{O}$ fluxes. These results suggest that it takes a long time to restore degraded agricultural land without additional fertilizer inputs. Our schedule files assume that enrollment of land in the CRP program began in 1987 , because the program was created in 1985 and land was thereafter gradually placed under contract. Results of these runs indicate that the retirement of land into CRP produced a large decrease in plant production and $\mathrm{N}_{2} \mathrm{O}$ emissions (due to the elimination of $\mathrm{N}$ fertilizer on $\mathrm{CRP}$ land), a slight reduction in $\mathrm{N}$ mineralization rates, and slow increases in soil C levels, similar to the results from the restoredpasture runs.

When we turn to simulations for Yuma County, we see that the impacts of observed historical changes in land use (Fig. 6) are similar to those for Hamilton County. The main differences stem from the later plowout of native grassland and delayed irrigation of corn fields in Yuma County. Peak soil C loss, net N mineralization, $\mathrm{N}_{2} \mathrm{O}$ emissions, and net $\mathrm{GHG}$ fluxes occurred later in Yuma County, and the later irrigation delayed the peak net GHG uptake for irrigated corn by 10 years; also, above-ground production for the Yuma County pasture and dryland cropping regimes is less than that for Hamilton County because of lower precipitation in Yuma County (an average of $41 \mathrm{~cm} / \mathrm{yr}$ as compared to $67 \mathrm{~cm} / \mathrm{yr}$ in Hamilton County).

Weld County differs from Yuma and Hamilton counties in that it is close to the Rocky Mountains, has the lowest annual precipitation of the three counties (averaging $32 \mathrm{~cm} / \mathrm{yr}$ ), and had access to flood irrigation water prior to the 20th century. The initial cultivtion of grassland for dryland and irrigated cropping started in the 1890s and cropping has continued to the present (2010). Crop rotations in the Weld County irrigated system used alfalfa (an N-fixing plant) and other perennial grasses to maintain soil fertility, and farmers also added animal manure to the soil. The simulated impacts of typical Great Plains agricultural practices on 


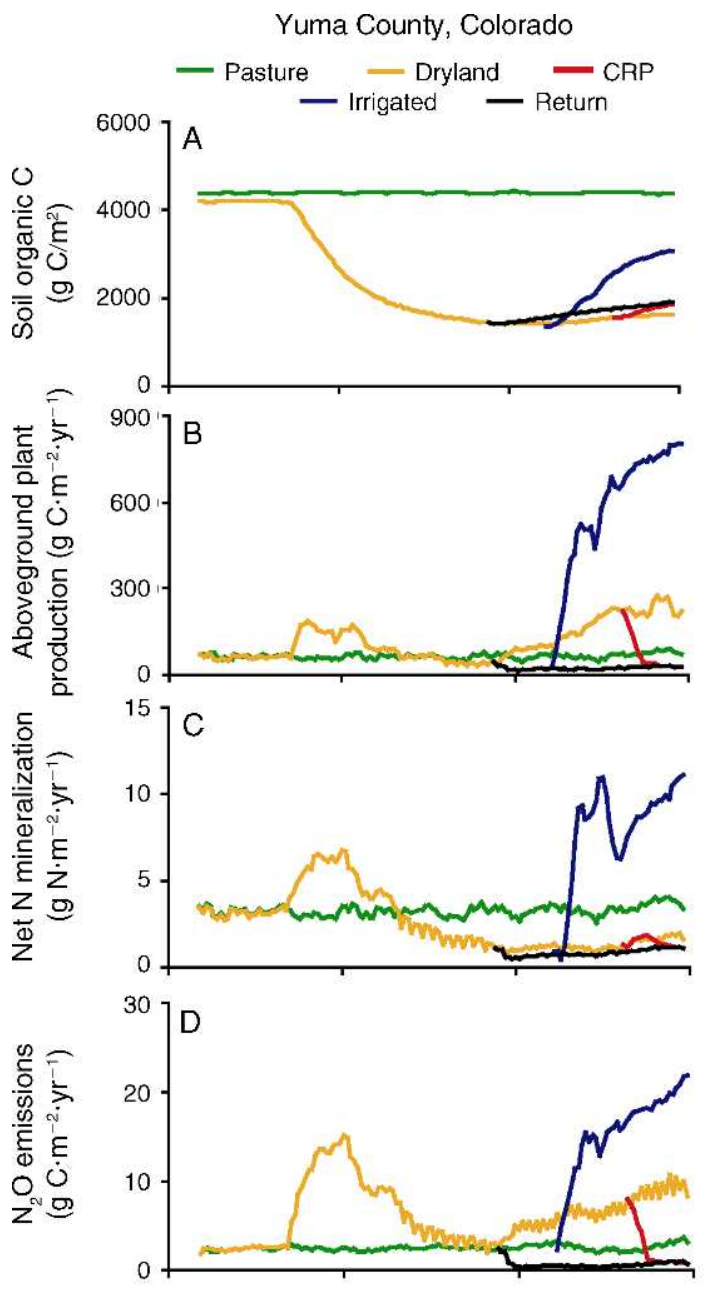

County increased following cultivation of the soil and have been maintained at high levels from 1900 to the present. The higher soil fertility of the irrigated system allows for greater plant production than in dryland agriculture, and results show a general pattern of increasing above-ground production (and therefore crop yields) for irrigated agriculture from the 1950s to the present as a result of improved crop varieties and

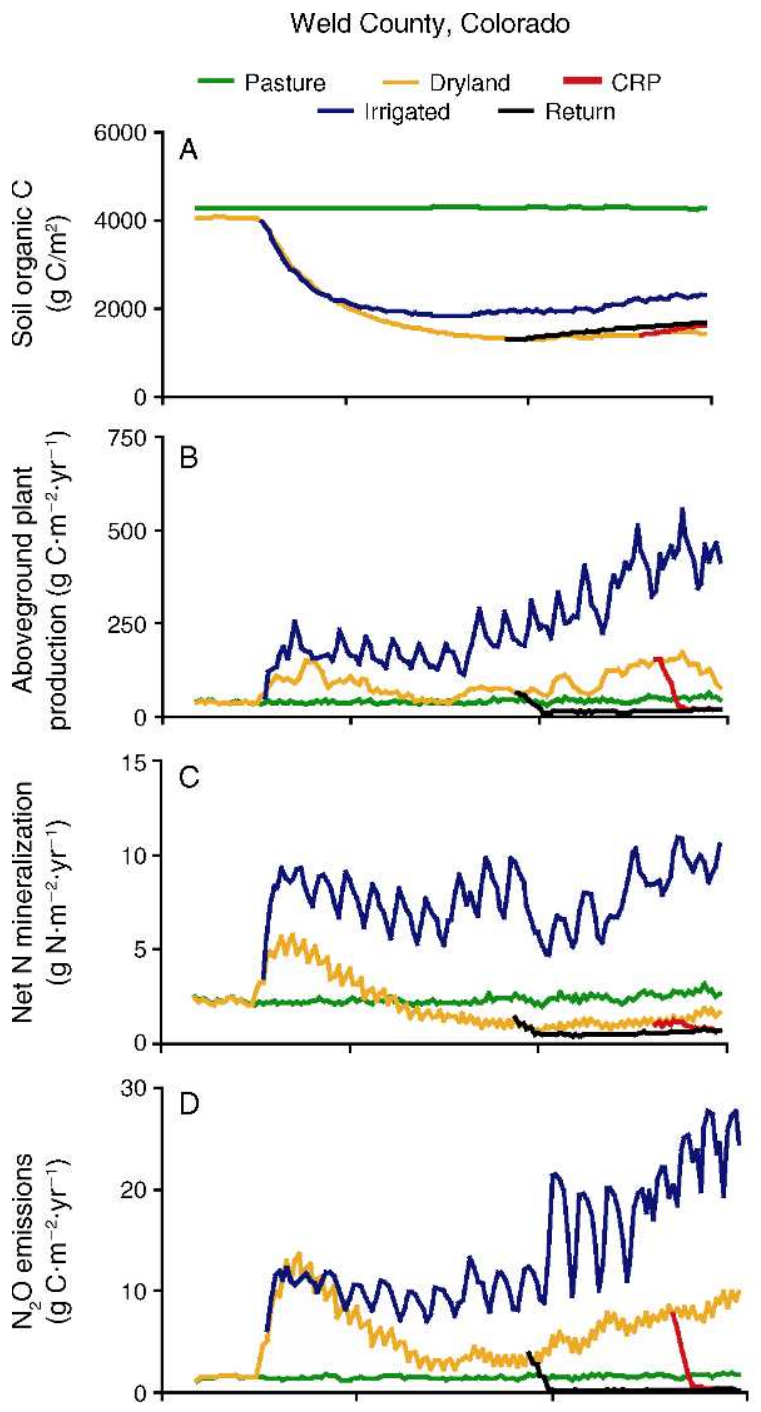

production, and $\mathrm{N}_{2} \mathrm{O}$ soil emissions in Weld County (Fig. 7) are generally consistent with results from Hamilton and Yuma counties (Figs. 5 and 6). The oscillatory behavior shown in Fig. 7 is a result of scheduling a rotation of grains, root crops, and alfalfa, which differ in annual production and $\mathrm{C}$ and $\mathrm{N}$ inputs to the soil. The primary difference between results for Weld and those for the other two counties is that the irrigated rotations in Weld show less $\mathrm{C}$ loss following the initiation of cultivation and exhibit a general pattern of increasing soil C from the 1930s to the present. Soil $\mathrm{N}$-mineralization rates for irrigated land in Weld

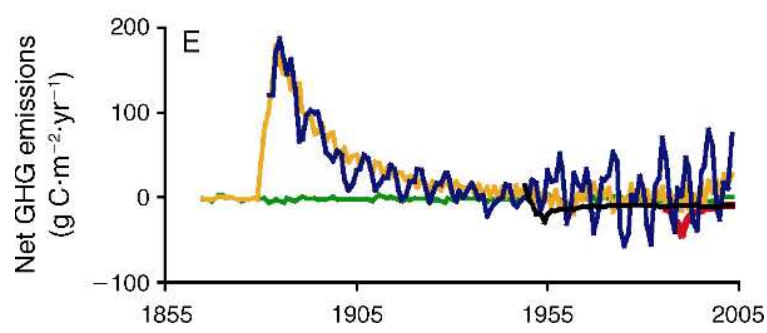

FIG. 7. Results for Weld County, Colorado, USA. The format is as in Fig. 5. 
increased fertilizer application. Comparing dryland crop and pasture production in Weld with that in Yuma and Hamilton counties demonstrates that Weld County has the lowest aboveground production of the three counties and that production increases as one moves eastward from Weld to Hamilton as a result of increasing annual precipitation. Soil $\mathrm{N}_{2} \mathrm{O}$ emissions for irrigated cropping in Weld County remained high from 1900 to 1950 compared to dryland cropping results and increased from 1950 to the present due to the increased application of $\mathrm{N}$ fertilizer. Furthermore, soil $\mathrm{N}_{2} \mathrm{O}$ emissions were higher for irrigated cropping in Weld than for irrigated agriculture in Yuma and Hamilton counties. The pattern of net GHG emissions for dryland agriculture, CRP land, and dryland returned to pasture are similar for all three counties; however, irrigated land in Weld County shows consistently higher net GHG emissions from the 1950 s to the present, as compared to the other counties, resulting from higher $\mathrm{N}_{2} \mathrm{O}$ emissions.

\section{Regional extrapolation}

Extrapolating our results to the entire Great Plains region indicates that agricultural lands in the Great Plains were a source of $1.73 \times 10^{15} \mathrm{~g}$ (or 1.73 petagrams [Pg]) $\mathrm{CO}_{2}-\mathrm{C}$ equivalents (sources minus sinks) from 1860 to 2003 , with $1.87 \mathrm{PgCO}_{2}-\mathrm{C}$ equivalents emitted from dryland croplands, primarily before 1950 (Table 2). For 1860 to 2003, restored grasslands (former cropland returned to pasture or enrolled in CRP) provided the largest net GHG sink $\left(1.02 \times 10^{14} \mathrm{~g} \mathrm{CO}_{2}\right.$-C equivalents), followed by pasture that was never plowed $\left(3.13 \times 10^{13} \mathrm{~g}\right.$ $\mathrm{CO}_{2}-\mathrm{C}$ equivalents), and irrigated cropland $\left(9.37 \times 10^{12}\right.$ $\mathrm{g} \mathrm{CO}_{2}$-C equivalents).

\section{DisCusSION}

In order to assess the environmental impact of landuse change in the U.S. Great Plains, we developed a detailed dataset that includes information about historical changes in crop rotations, tillage practices, organic and inorganic nutrient additions, crop varieties, and crop yields at a subregional scale for the Great Plains. This greatly expands on the currently available land-use data for the region (Ramankutty and Foley 1999).

Using this data set along with available data on climate and soils to drive the DAYCENT model, we simulated historical changes in crop yields for major crops of the Great Plains and matched them with observed crop yields. Historical changes in crop varieties, residue removal practices, intensity and occurrence of soil tillage, and addition of organic and inorganic fertilizer were the main factors considered in the crop-yield calibration process. The observed and simulated historical data for dryland corn and wheat show a consistent pattern of high yields for 10 years following initial cultivation ("plowout") of the grasslands, a gradual pattern of decreasing crop yields until the 1930s, and increasing crop yields from the 1940s to the present (2010). These crops show the same historical pattern under irrigation, but with substantially higher crop yields.

The DAYCENT model results for irrigated and dryland wheat and corn suggest that higher yields immediately following plowout of the prairie resulted from enhanced soil nutrient mineralization, which quickly decreased with the removal of nutrients via harvested crop material. Model results show a decline in soil organic $\mathrm{C}$ and net $\mathrm{N}$ mineralization with continued dryland cropping, suggesting that the loss of soil fertility caused the decline in dryland crop yields from the 1920s through the 1950s, though below-average precipitation in the 1930s was also a factor. This finding is consistent with studies that have documented a pattern of decreasing crop yields following the plowout of grasslands (Haas and Evans 1957, Rasmussen and Parton 1994). Model results showing high $\mathrm{N}$-mineralization rates following plowout accord with observations that $\mathrm{N}$ fertilizer responses are minimal for Great Plains dryland wheat fields cultivated less than 30 years (Greb et al. 1974, Metherell et al. 1995). Increasing crop yields from the 1940 s to the present have been produced by a continuing rise in the use of improved crop varieties, inorganic fertilizer, pesticides and herbicides, and in some cases, irrigation; the impact of these changes is well documented (Matson et al. 1997, Parton et al. 2005, 2007). Those studies indicate that the increased use of $\mathrm{N}$ fertilizer under irrigation has resulted in the leaching of nitrate into groundwater, the movement of pesticides and herbicides into stream water, and increased $\mathrm{N}_{2} \mathrm{O}$ fluxes (Vitousek et al. 1997, Del Grosso et al. 2005, $2008 a, b)$.

The results of our model verification and validation processes demonstrate that we achieved a good match between mean simulated and observed crop yields for the main crops, particularly wheat and corn. However, the model is unable to replicate all interannual variability in crop yields, despite the high level of detail in our representation of agricultural history, $\mathrm{N}$ inputs, soils, and climate. The model performs better on irrigated crops than dryland crops because irrigation reduces variation in water stress. Although model performance metrics indicated a closer fit between simulated and observed yields in verification counties than in validation counties for all comparisons except dryland wheat (Table 1), we believe that the reduction in model performance in the validation counties is relatively small, and that our schedule files are general enough to be applied to other nearby counties without having to recalibrate each time.

Uncertainty in DAYCENT-simulated greenhouse-gas (GHG) fluxes from U.S. croplands has been previously evaluated with Monte Carlo analysis (Del Grosso et al. 2010). That assessment included estimates of uncertainty associated with model input variables (i.e., $\mathrm{N}$ inputs from fertilizer and manure and daily weather data) and structural uncertainty associated with the ability of the model to simulate observed data. The $95 \%$ confidence 
interval was estimated to be $-35 \%$ to $+50 \%$ for annual $\mathrm{N}_{2} \mathrm{O}$ emissions aggregated to the national scale. A formal uncertainty analysis of the simulated DAYCENT crop yields has not been performed. Some of the errors in simulated crop yields result from natural disasters, such as floods, hail, and high winds, which are not considered in the model.

Model results for dryland agriculture show that the conversion of grassland to dryland cropping resulted in a large loss of soil $\mathrm{C}$ and an increase in soil $\mathrm{N}_{2} \mathrm{O}$ emissions, translating into a substantial net release of GHG during the 50-year period following plowout (1900 to 1950), and most rapidly during the first 20 years of cropping. After 1950, substantial improvements in dryland agricultural practices, such as the introduction of more-productive crop varieties, the addition of $\mathrm{N}$ fertilizer (increasing with time after 1950), and the use of less damaging soil-cultivation practices (Parton et al. 2007), produced large increases in crop yields, gradual increases in soil $\mathrm{N}$-mineralization rates and soil C levels, and substantial increases in soil $\mathrm{N}_{2} \mathrm{O}$ emissions. Results show a general pattern of net negative GHG fluxes in the 1960s and 1970s, though this GHG sink gradually diminished, driven by the rise in soil $\mathrm{N}_{2} \mathrm{O}$ emissions from increasing $\mathrm{N}$-fertilizer applications after 1950. The simulated large losses of soil $\mathrm{C}$ following the plowout of native grasslands are confirmed by studies that show a loss of $\sim 50 \%$ of soil C after 50 years of cultivation (Haas and Evans 1957, Metherell et al. 1995). Simulated soil $\mathrm{N}_{2} \mathrm{O}$ emissions from dryland agriculture in the Great Plains during the last 20 years agree with field observations (Mosier et al. 1997). The simulated trend of increasing soil $\mathrm{N}_{2} \mathrm{O}$ fluxes beginning in the 1960 s is consistent with the pattern of increasing $\mathrm{N}$-fertilizer applications during the same period (Matson et al. 1997) and with the observation that $\sim 1 \%$ of the $\mathrm{N}$ inputs (synthetic fertilizer, manure, residues, etc.) is lost as soil $\mathrm{N}_{2} \mathrm{O}$ emissions (Del Grosso et al. 2008c). Extrapolating our results to estimate the net GHG flux from dryland cropping in the Great Plains between 1860 and 2003 suggests a net $\mathrm{GHG}$ release of $1.87 \quad \mathrm{Pg} \mathrm{CO}_{2}-\mathrm{C}$ equivalents.

The simulations for land enrolled in the USDA Conservation Reserve Program (CRP) or otherwise retired from crop production demonstrate the impact of restoring grasslands at different times during the last 60 years (1950-1970 for dryland cropland returned to pasture, and 1987 for CRP). These model results show that soil $\mathrm{C}$ and plant production increase slowly following the cessation of cropping, and that soil $\mathrm{N}_{2} \mathrm{O}$ emissions are substantially lower in the restored grassland than in fertilized dryland agriculture. Data from the U.S. Census of Agriculture (see footnote 6) demonstrate that nontrivial amounts of land came out of dryland cropping systems in the second half of the 20th century, and the DAYCENT model reveals that the effect is a substantial reduction in net GHG fluxes (net sink) and the initiation of the slow process (in the absence of fertilization) of restoring soil fertility and plant production. Our simulations compare well with observations of soil C storage (Burke et al. 1995, Robles and Burke 1997, 1998, Kucharik 2007), low soil $\mathrm{N}_{2} \mathrm{O}$ emissions (Mosier et al. 1997), and low soil Nmineralization rates (Robles and Burke 1998) in cropland taken out of production. These results suggest that the total net GHG reduction associated with the removal of cropland from production and the enrollment of land in CRP could be substantial, since more than 38 million acres ( 1 acre $=0.405$ ha) of formerly cropped land in the Great Plains are currently out of production. Extrapolating from the net GHG reductions in our 21 representative counties, we estimate a net GHG sink from out-of-production land (CRP plus dryland cropland returned to pasture) of $1.02 \times 10^{14} \mathrm{~g}$ $\mathrm{CO}_{2}-\mathrm{C}$ equivalents between 1950 and 2003, which is $\sim 7 \%$ of the net GHG emitted during the 1860-1949 plowout period.

Irrigation in the Great Plains began in 1900 with gravity-flow systems in counties near the Rocky Mountains, including Weld County, Colorado. Irrigated-model results for Weld County show that the initial plowout of grassland for irrigated cropping resulted in large losses of soil $\mathrm{C}$, large net GHG fluxes, and high levels of soil $\mathrm{N}_{2} \mathrm{O}$ emissions, similar to those found in the dryland agricultural runs. However, a comparison of irrigated and dryland model runs for Weld County indicates that soil C losses following plowout were less dramatic in irrigated cropland, and that soil $\mathrm{N}_{2} \mathrm{O}$ emissions, net $\mathrm{N}$ mineralization, and plant production were substantially higher. Weld County's irrigated schedule files include alfalfa (an N-fixing plant); the additional $\mathrm{N}$ it provides supports plant production, mediates the depletion of soil $\mathrm{C}$, and enhances soil $\mathrm{N}$-mineralization rates. Irrigation in the Great Plains expanded substantially in the 1950s with center-pivot pump irrigation systems drawing water from the Ogallala Aquifer, as exemplified by Yuma County, Colorado, and Hamilton County, Nebraska. Because irrigation began later in these counties, it occurred on soils degraded by decades of dryland agriculture, which had a greater potential to sequester C. Irrigation therefore caused a net reduction in GHG fluxes (negative fluxes). However, irrigated simulations for Yuma and Hamilton counties also demonstrate that, after this initial absorption of GHGs, the linear increase in soil $\mathrm{N}_{2} \mathrm{O}$ emissions caused by intensifying fertilizer application produced increasingly positive net GHG fluxes from the 1970s to the present. Model results for all irrigated runs (in Weld, Yuma, and Hamilton counties) show a similar pattern after the 1950 s, with soil C levels, plant production, and soil $\mathrm{N}_{2} \mathrm{O}$ emissions increasing as a result of the use of improved plant varieties and greater $\mathrm{N}$-fertilizer inputs. These findings are supported by observed crop yield data (Parton et al. 2007), irrigated crop soil $\mathrm{N}_{2} \mathrm{O}$ flux data (Del Grosso et al. 2008a), and observed irrigated crop soil $\mathrm{C}$ change data from the last 
40 years (Entry et al. 2002, Lal 2004). Extrapolating from model results for irrigated cropland in the 21 representative counties, we estimate a net GHG sink of $2.44 \times 10^{13} \mathrm{~g} \mathrm{CO}_{2}-\mathrm{C}$ equivalents from 1950 to 2003 in the region as a whole, which is $24 \%$ of the net GHG sink resulting from land retired during the same period.

\section{Conclusions}

This paper offers an innovative set of methods for assessing the environmental effects of 120 years of cropping in the U.S. Great Plains. Building on work reported earlier (Gutmann et al. 2005, Parton et al. 2005), we showed that it is possible to represent a broad range of agricultural practices and environmental settings with a limited set of biogeochemical model specifications. By driving the DAYCENT model with historically accurate data indicating daily agricultural practices in 21 representative Great Plains counties over 120 years, we have simulated a time series of annual soil $\mathrm{C}$ levels, $\mathrm{N}$-mineralization rates, and net GHG fluxes from 1860 to 2003 at the subregional level, and produced cumulative estimates of GHG emissions for the region as a whole. This paper focuses on these 21 counties, but future work will extend our analysis to all 476 counties.

\section{ACKNOWLEDGMENTS}

This research was supported by Grant Number R01HD33554 from the Eunice Kennedy Shriver National Institute of Child Health and Human Development and by the Short Grass Steppe Long Term Ecological Research Site (NSF Grant DEB-0823405) at Colorado State University. We are grateful to Cindy Keough for her assistance with the DAYCENT model, to Glenn Deane for statistical consultation, and to Laurie Richards for editorial assistance. This material was partly based on work supported by the National Science Foundation while Myron Gutmann was working at the Foundation. Any opinion, finding, conclusions, or recommendations expressed in this material are those of the authors and do not necessarily reflect the views of the National Science Foundation.

\section{Literature Cited}

Burke, I. C., W. K. Lauenroth, and D. P. Coffin. 1995. Soil organic-matter recovery in semiarid grasslands: implications for the conservation reserve program. Ecological Applications 5:793-801.

Clark, J. M. 1904. Potato culture near Greeley, Colorado. Pages 311-32 in 1904 Yearbook of the Department of Agriculture. U.S. Government Printing Office, Washington, D.C., USA.

Cunfer, G. 2005. On the Great Plains: agriculture and environment. Texas A\&M University Press, College Station, Texas, USA.

Dalrymple, D. G. 1988. Changes in wheat varieties and yields in the United States, 1919-1984. Agricultural History 62:20-36.

Del Grosso, S. J., A. D. Halvorson, and W. J. Parton. 2008 a. Testing DAYCENT model simulations of corn yields and nitrous oxide emissions in irrigated tillage systems in Colorado. Journal of Environmental Quality 37:1383-1389.

Del Grosso, S. J., A. R. Mosier, W. J. Parton, and D. S. Ojima. 2005. DAYCENT model analysis of past and contemporary soil $\mathrm{N}_{2} \mathrm{O}$ and net greenhouse gas flux for major crops in the USA. Soil \& Tillage Research 83:9-24.

Del Grosso, S. J., S. M. Ogle, W. J. Parton, and F. J. Breidt. 2010. Estimating uncertainty in $\mathrm{N}_{2} \mathrm{O}$ emissions from U.S. cropland soils. Global Biogeochemical Cycles 24:1-12.
Del Grosso, S. J., W. J. Parton, A. R. Mosier, D. S. Ojima, A. E. Kulmala, and S. Phongpan. 2000. General model for $\mathrm{N}_{2} \mathrm{O}$ and $\mathrm{N}-2$ gas emissions from soils due to dentrification. Global Biogeochemical Cycles 14:1045-1060.

Del Grosso, S. J., W. J. Parton, A. R. Mosier, M. K. Walsh, D. S. Ojima, and P. E. Thornton. 2006. DAYCENT national-scale simulations of nitrous oxide emissions from cropped soils in the United States. Journal of Environmental Quality 35:1451-1460.

Del Grosso, S. J., W. J. Parton, D. S. Ojima, C. A. Keough, T. H. Riley, and A. R. Mosier. 2008b. DAYCENT simulated effects of land use and climate on county level $\mathrm{N}$ loss vectors in the USA. Pages 571-595 in J. L. Hatfield and R. F. Follett, editors. Nitrogen in the envrionment: sources, problems, and management. Second edition. Elsevier Science Publishers, Oxford, UK.

Del Grosso, S. J., T. Wirth, S. M. Ogle, and W. J. Parton. $2008 c$. Estimating agricultural nitrous oxide emissions. EOS 89:529-530.

Entry, J. A., R. E. Sojka, and G. E. Shewmaker. 2002. Management of irrigated agriculture to increase organic carbon storage in soils. Soil Science Society of America Journal 66:1957-1964.

Food Security Act. 1985. 23 December 1985. Public Law 99-198. Statutes at Large 99:1554.

Forster, P., et al. 2007. Changes in atmospheric constituents and in radiative forcing. Pages 129-234 in S. Solomon, D. Qin, M. Manning, Z. Chen, M. Marquis, K. B. Averyt, M. Tignor, and H. L. Miller, editors. Climate change 2007: the physical science basis. Contribution of Working Group I to the Fourth Assessment Report of the Intergovernmental Panel on Climate Change. Cambridge University Press, Cambridge, UK.

Greb, B. W., D. E. Smika, N. P. Woodruff, and C. J. Whitfield. 1974. Summer fallow in the central Great Plains. Pages 51-85 in Conservation Research Report. Volume 17. U.S. Department of Agriculture, Washington, D.C., USA.

Griliches, Z. 1960. Hybrid corn and the economics of innovation. Science 132:275-280.

Gutmann, M. P. 2005a. Great Plains population and environment data: social and demographic data, 1870-2000 United States. ICPSR study number 4296. Volume 2. 2007-02-07. Inter-University Consortium for Political and Social Research, University of Michigan, Ann Arbor, Michigan, USA.

Gutmann, M. P. 2005b. Great Plains population and environment data: agricultural data 1870-1997 United States. ICPSR study number 4254. Volume 200506-22. InterUniversity Consortium for Political and Social Research, University of Michigan, Ann Arbor, Michigan, USA.

Gutmann, M. P., W. J. Parton, G. Cunfer, and I. C. Burke. 2005. Population and environment in the U.S. Great Plains. Pages $84-105$ in B. Entwisle and P. C. Stern, editors. Population, land use, and environment: research directions. National Academy of Sciences Press, Washington, D.C., USA.

Haas, H. J., and C. E. Evans. 1957. Nitrogen and carbon changes in Great Plains soils as influenced by cropping and soil treatments. USDA Technical Bulletin 1164. U.S. Government Printing Office, Washington, D.C., USA.

Helms, D. 1990. Conserving the Plains: the Soil Conservation Service in the Great Plains. Agricultural History 64:58-73.

Janssen, P. H. M., and P. S. C. Heuberger. 1995. Calibration of process-oriented models. Ecological Modelling 83:55-66.

Kelly, R. H., W. J. Parton, G. J. Crocker, P. R. Grace, J. Klir, M. Korschens, P. R. Poulton, and D. D. Richter. 1997. Simulating trends in soil organic carbon in long-term experiments using the century model. Geoderma 81:75-90.

Kittel, T. G. F., et al. 2004. VEMAP phase 2 bioclimatic database. I. Gridded historical (20th century) climate for modeling ecosystem dynamics across the conterminous USA. Climate Research 27:151-170. 
Kucharik, C. J. 2007. Impact of prairie age and soil order on carbon and nitrogen sequestration. Soil Science Society of America Journal 71:430-441.

Lal, R. 2004. Carbon sequestration in dryland ecosystems. Environmental Management 33:528-544.

Lokupitiya, E., F. J. Breidt, R. Lokupitiya, S. Williams, and K. Paustian. 2007. Deriving comprehensive county-level crop yield and area data for U.S. cropland. Agronomy Journal 99:673-681.

Matson, P. A., W. J. Parton, A. G. Power, and M. J. Swift. 1997. Agricultural intensification and ecosystem properties. Science 277:504-509.

Metherell, A. K., C. A. Cambardella, W. J. Parton, G. A. Peterson, L. A. Harding, and C. V. Cole. 1995. Simulation of soil organic matter dynamics in dryland wheat-fallow cropping systems. Pages 259-270 in R. Lal, J. Kimball, E. Levine, and B. A. Stewart, editors. Soil management and greenhouse effect. CRC Press, Boca Raton, Florida, USA.

Metherell, A. K., L. A. Harding, C. V. Cole, and W. J. Parton. 1993. CENTURY: soil organic matter model. Technical Document, Agroecosystems version 4.0. Great Plains Systems Research Unit, Tech Report Number 4. USDA-ARS, Fort Collins, Colorado, USA.

Mosier, A. R., W. J. Parton, D. W. Valentine, D. S. Ojima, D. S. Schimel, and O. Heinemeyer. 1997. $\mathrm{CH}_{4}$ and $\mathrm{N}_{2} \mathrm{O}$ fluxes in the Colorado shortgrass steppe: 2. Long-term impact of land use change. Global Biogeochemical Cycles 11:29-42.

Parton, W. J., M. P. Gutmann, and D. Ojima. 2007. Long-term trends in population, farm income, and crop production in the Great Plains. BioScience 57:737-747.

Parton, W. J., M. P. Gutmann, S. A. Williams, M. Easter, and D. Ojima. 2005. Ecological impact of historical land-use patterns in the Great Plains: a methodological assessment. Ecological Applications 15:1915-1928.

Parton, W. J., M. Hartman, D. Ojima, and D. Schimel. 1998. DAYCENT and its land surface submodel: description and testing. Global and Planetary Change 19:35-48.

Parton, W. J., E. A. Holland, S. J. Del Grosso, M. D. Hartman, R. E. Martin, A. R. Mosier, D. S. Ojima, and D. S. Schimel. 2001. Generalized model for $\mathrm{NO}_{x}$ and $\mathrm{N}_{2} \mathrm{O}$ emissions from soils. Journal of Geophysical Research-Atmospheres 106:17403-17419.

Parton, W. J., A. R. Mosier, D. S. Ojima, D. W. Valentine, D. S. Schimel, K. Weier, and A. E. Kulmala. 1996. Generalized model for $\mathrm{N}-2$ and $\mathrm{N}_{2} \mathrm{O}$ production from nitrification and denitrification. Global Biogeochemical Cycles 10:401-412.

Parton, W. J., and P. E. Rasmussen. 1994. Long-term effects of crop management in wheat-fallow: II. CENTURY model simulations. Soil Science Society of America Journal 58:530 536.

Parton, W. J., J. M. O. Scurlock, D. S. Ojima, T. G. Gilmanov, R. J. Scholes, D. S. Schimel, T. Kirchner, J. C. Menaut, T. Seastedt, E. G. Moya, A. Kamnalrut, and J. I. Kinyamario. 1993. Observations and modeling of biomass and soil organic-matter dynamics for the grassland biome worldwide. Global Biogeochemical Cycles 7:785-809.

Peterson, G. A., A. D. Halvorson, J. L. Havlin, O. R. Jones, D. J. Lyon, and D. L. Tanaka. 1998. Reduced tillage and increasing cropping intensity in the Great Plains conserves soil C. Soil \& Tillage Research 47:207-218.

Ramankutty, N., and J. A. Foley. 1999. Estimating historical changes in global land cover: croplands from 1700 to 1992. Global Biogeochemical Cycles 13:997-1027.

Rasmussen, P. E., and W. J. Parton. 1994. Long-term effects of residue management in wheat-fallow 1. Inputs, yield, and soil organic matter. Soil Science Society of America Journal 58:523-530.

Robles, M. D., and I. C. Burke. 1997. Legume, grass, and conservation reserve program effects on soil organic matter recovery. Ecological Applications 7:345-357.

Robles, M. D., and I. C. Burke. 1998. Soil organic matter recovery on conservation reserve program fields in southeastern Wyoming. Soil Science Society of America Journal 62:725-730.

Ruddy, B. C., D. L. Lorenz, and D. K. Mueller. 2006. Countylevel estimates of nutrient inputs to the land surface of the conterminous United States, 1982-2001. U.S. Geological Survey Scientific Investigations Report 2006-5012.

Thornton, P. E., S. W. Running, and M. A. White. 1997. Generating surfaces of daily meteorological variables over large regions of complex terrain. Journal of Hydrology 190:214-251.

USDA [U.S. Department of Agriculture]. 2007. National Agricultural Statistics Service: the fact finders of agriculture. USDA National Agricultural Statistics Service, Washington, D.C., USA.

Vitousek, P. M., J. D. Aber, R. W. Howarth, G. E. Likens, P. A. Matson, D. W. Schindler, W. H. Schlesinger, and G. D. Tilman. 1997. Human alteration of the global nitrogen cycle: Sources and consequences. Ecological Applications 7:737750 .

\section{APPENDIX A}

Generalized cropland systems (Ecological Archives A021-049-A1).

\section{APPENDIX B}

Model performance measures comparing model crop-yield predictions against crop-yield observations by county (Ecological Archives A021-049-A2). 